\title{
Europe seeks single defence research agency
}

\section{Quirin Schiermeier, Munich}

European policy-makers are thinking of setting up a counterpart to the US Defense Advanced Research Projects Agency (DARPA). The US organization enjoys a reputation as a forward-thinking supporter of innovative research.

Greece, which this month took over the rotating presidency of the European Union $(\mathrm{EU})$, is expected to ask the European Commission to draw up a set of options to beef up Europe's military research programmes, and foster multilateral cooperation in fundamental defence-related research.

At a meeting of EU commissioners in Athens earlier this month, Yiannos Papantoniou, the Greek defence minister, said that he favours either an extension of the EU Framework research programme to include military and 'dual use' research, or the creation of an agency similar to DARPA.

DARPA plays an important role in supporting basic, openly published scientific research at US universities, especially in disciplines such as materials, computer science and engineering.

Most of Europe's defence-related research is carried out by national agencies. "This has led to fragmentation and duplication of research," argues Jordi Molas-Gallart, a defence research analyst at the Science and Technology Policy Research unit at the University of Sussex, UK. "There is scope for much more coordination - but there are also entrenched national misgivings and strategic concerns."

The EU's six biggest weapons-buying nations - France, Italy, Spain, Sweden, Germany and Britain - signed a memorandum in 2000 to cooperate on military procurement. But this had no effect on scientific research, says Molas-Gallart.

Last year, a working group of the European Convention, which is to draft a new framework and structures for the EU by 2004, proposed the creation of a European armaments and strategic research agency, which would promote harmonized procurement and research.

But a basic research agency like DARPA, with scientific autonomy and a mission to address generic, high-risk ideas in various disciplines, would take that concept a step further. "A European DARPA, if it avoids EU bureaucracy, could become a clearing house for advanced technologies for military and civilian applications," says Alex Nicoll, assistant director of the London-based International Institute for Strategic Studies.

European officials say that EU research commissioner Philippe Busquin is open to the idea in principle. "It is surely an option, but it is at a very early stage," says a spokesman for the commission.
Nicoll believes there is political will to strengthen the EU's military role, but warns that without a common defence policy, any EU defence-research programme could fail.

The gap in defence spending between the United States and its 17 European allies has been growing. In 2001, the United States spent almost $\$ 30,000$ per service person on $\mathrm{R} \& \mathrm{D}$ - twice as much as Britain, more than three times as much as France, and almost ten times as much as Germany, according to the IISS. Basic and applied research related to military needs received $\$ 14$ billion in the United States, compared with $\$ 7$ billion in France, Britain and Germany combined. www.weu.int/weag www.ifiss.org

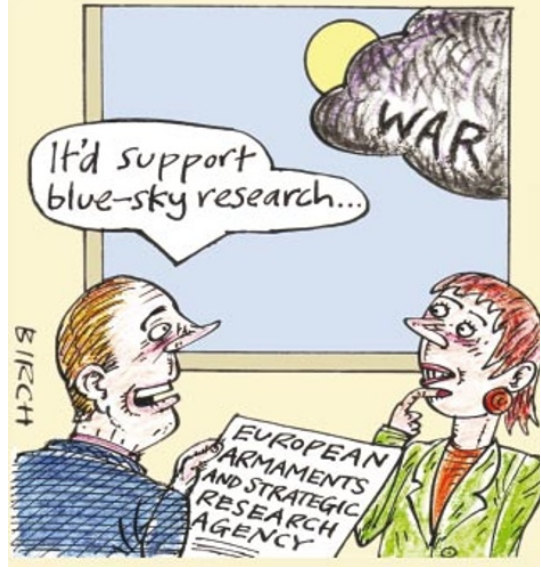

\section{Italians riled by science reforms}

Alison Abbott, Munich

Top Italian researchers have lambasted the research ministry for what they call an unconstitutional effort to grab direct control of the CNR, the country's leading basic-research organization.

The scientists are angry that under a decree made public on 24 January, the research ministry would acquire the power to appoint key figures within the CNR, which would be restructured to focus on applications of research. The researchers also complain that they were not consulted. They have now been given two months to comment on the decree.

Lucio Bianco, president of the CNR, says he will make sure that the legality of the decree is challenged in court if the government refuses to modify its contents. "Autonomy of scientific research institutes,

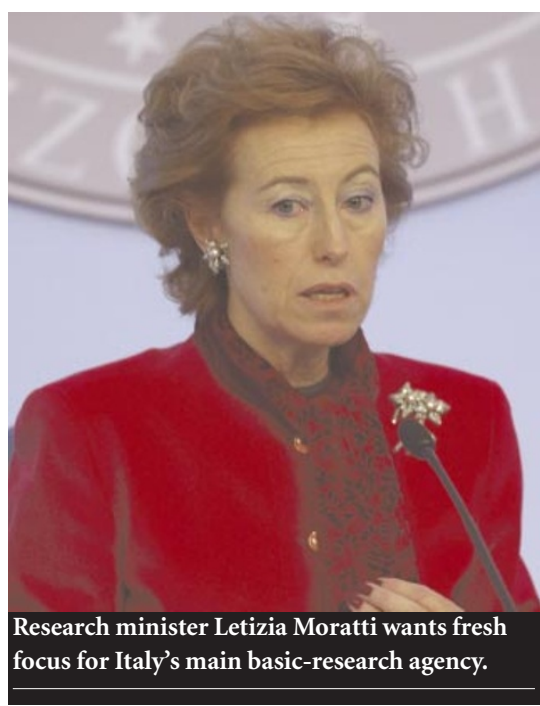

universities and academies is guaranteed in the Italian constitution," he argues.

The plan would divide the CNR, which runs some 100 institutes, into disciplinerelated departments whose heads will be appointed by the ministry. Department heads would be responsible for allocating resources and nominating institute directors. The names of the departments, such as 'science and technologies of medicine', or 'science and technologies of advanced production systems', strongly emphasize the applications of research.

Education, university and research minister Letizia Moratti says that her proposed new structure will make the best use of available resources. But Carlo Bernardini, a high-energy physicist from the University of Rome, says it is ill-conceived. "No one argues against making research more productive, but you can't do this by putting in managers to steer basic research," he says. Bernardini is unhappy that the ministry used the consultancy firm Ernst and Young to develop the strategy, "but excluded scientists - even the presidents of basic research organizations".

"Scientists see this as an attack on the autonomy of research," says Rino Falcone, of the CNR Institute of Cognitive Sciences and Technology in Rome, who has organized protests against the decree.

The decree also rearranges some organizations, bringing the INFM, an agency for material sciences that was spun out from the CNR in 1994, back inside it, and transferring the CNR's astrophysics institutes to the Institute of Astronomy, formed by a merger of Italy's 12 observatories in 2000. 